Alma Mater Studiorum - Università di Bologna DEPARTMENT OF ECONOMICS

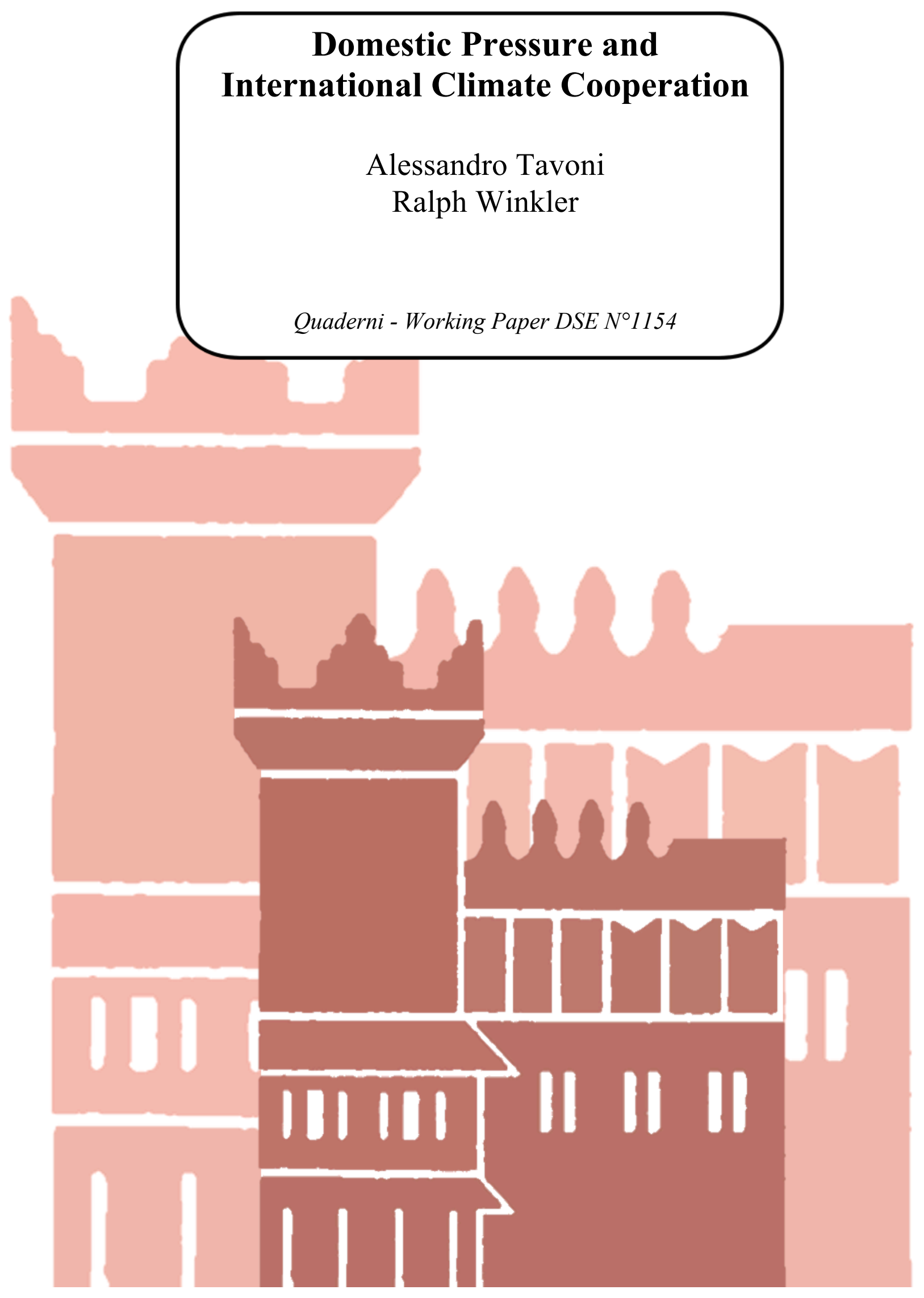




\section{Domestic Pressure and International Climate Cooperation}

October 29, 2020

\section{Alessandro Tavoni ${ }^{1}$ and Ralph Winkler ${ }^{2}$}

Keywords: international climate cooperation, hierarchical policy-making, domestic pressure, special interest groups, (strategic) delegation

Abstract: In the wake of 25 UN Climate Change Conferences of the Parties (and counting), international cooperation on mitigating greenhouse gas emissions to avoid substantial and potentially irreversible climate change remains an important challenge. The limited impact that the Kyoto Protocol and its successor, the Paris Agreement, have had on curbing emissions demonstrate both the difficulties in negotiating ambitious environmental agreements and the reluctance of countries to comply with their agreed emission targets once they have joined the treaty. Therefore, a better understanding of the obstacles and opportunities that the interactions between domestic and international policy pose for the design of successful international climate cooperation is of utmost importance. To shed light on the roots of the stalemate (and suggest possible ways out), this article reviews, and draws lessons from, a growing theoretical, experimental and empirical literature that accounts for the hierarchical interplay between domestic political pressure and international climate policy.

\footnotetext{
${ }^{1}$ Department of Economics, University of Bologna, Italy, 40126 and Grantham Research Institute on Climate Change and the Environment, London School of Economics, U.K., WC2A2AE. alessandro.tavoni2@unibo.it

${ }^{2}$ Department of Economics and Oeschger Centre for Climate Change Research, University of Bern, Schanzeneckstr. 1, CH-3012 Bern, Switzerland
} 


\section{Non-technical summary}

The world in which climate policies are negotiated, legislations passed and interventions implemented has thus changed dramatically since the signing of the Paris Agreement. Meanwhile, four more rounds of conferences have taken place (COP26 has been postponed to 2021 due to the COVID-19 pandemic), with disappointing results both at COP24 in Katowice and COP25 in Madrid. In short, the Paris treaty is under threat, due to an increasing number of countries opposing coordinated action to address global climate change. An important consequence is that the void left by the lack of international leadership in certain governments paves the way for lower levels of governance becoming more prominent: domestic actors (e.g., cities, firms and citizens) have a much greater role in achieving the agreed target of keeping the global temperature rise below $2^{\circ} \mathrm{C}$. In turn, the new regime's greater complexity relative to its top-down predecessor (the Kyoto Protocol), stemming from the multiplicity of actors involved, increases coordination costs and entails greater scope for strategic interactions between actors with wide-ranging interests (Chan et al. 2018).

To shed light on the roots of the stalemate (and suggest possible ways out), this article reviews, and draws lessons from, a growing theoretical, experimental and empirical literature that accounts for the hierarchical interplay between domestic political pressure and international climate policy. This review takes stock of this body of work through the lens of political economy and game theory, in order to shed light on the strategic incentives for cooperation at different scales and under multiple behavioral and political economy constraints. Specifically, we focus selectively on recent literature that studies how (environmental) cooperation is affected by the following forms of domestic pressure: electoral delegation (both strategic and non-strategic), lobbying and media capture by special interest groups, and the impact of domestic influences on the depth of (and participation to) international climate policies. The overarching theme of the review is the focus on a hierarchical notion of policy making: we concentrate on studies that either explicitly or implicitly shed light on how domestic political competition in a country affects the country's international policy. Due to constraints on data availability, most of the reviewed works are theoretical or experimental, although we have included a selection of empirical papers on lobbying and media capture. 


\section{INTRODUCTION}

Despite the perceived success of the Paris Agreement, which was widely acclaimed by many observers and politicians as a diplomatic breakthrough in international climate policy, anthropogenic climate change remains one of humanity's most pressing challenges. As with previous agreements, such as the Kyoto Protocol, we observe little progress in climate change mitigation: in almost all countries, current greenhouse gas (GHG) emissions are above the agreed upon pledges and even complying with these pledges would not achieve the acknowledged policy goal of containing the increase of the average surface temperature below $2^{\circ} \mathrm{C}$ compared to the pre-industrial levels. The main reasons are the public good characteristic of GHG emission reductions and the absence of a supranational authority that can enforce cooperation.

The landmark deal agreed in Paris late in 2015 indeed managed to secure almost universal support by essentially allowing states to set their own targets, so as not to impinge on their sovereignty while attempting to keep the global temperature rise in check. But the very next year witnessed the Brexit referendum in the UK, which initiated its withdrawal process from the EU, and the election of Donald Trump in the US. Both instances are often cited for marking the beginning of the recent surge in anti-globalism and nationalism worldwide, recent manifestations of which are the election of Jair Bolsonaro in Brazil and the spread of the yellow vests movement within France and in other countries.

The world in which climate policies are negotiated, legislations passed and interventions implemented has thus changed dramatically since the signing of the Paris Agreement. Meanwhile, four more rounds of conferences have taken place (COP26 has been postponed to 2021 due to the COVID-19 pandemic), with disappointing results both at COP24 in Katowice and COP25 in Madrid. Michal Kurtyka, who presided COP24 said that the mood among delegates had changed: "The appetite for multilateral solutions is not as it was in 2015". UN secretary general António Guterres voiced similar disappointment after the inconclusive Spanish summit took place: "The international community lost an important opportunity to show increased ambition on mitigation, adaptation and finance to tackle the climate crisis." In short, the Paris treaty is under threat, due to an increasing number of countries opposing coordinated action to address global climate change.

An important consequence is that the void left by the lack of international leadership in certain governments paves the way for lower levels of governance becoming more prominent: domestic actors (e.g., cities, firms and citizens) have a much greater role in achieving the agreed target of keeping the global temperature rise below $2^{\circ} \mathrm{C}$. In turn, the new regime's greater complexity relative to its top-down predecessor (the Kyoto Protocol), stemming from the multiplicity of actors involved, increases coordination costs and entails greater scope for strategic interactions between actors with wide-ranging interests (Chan et al. 2018). 
An expanding literature has recently developed to tackle the interplay between domestic and international policy, using theory, experiments and empirics to assess the prospects of cooperation in the increasingly fragmented "climate commons". This review takes stock of this body of work through the lens of political economy and game theory, in order to shed light on the strategic incentives for cooperation at different scales and under multiple behavioral and political economy constraints. Specifically, we focus selectively on recent literature that studies how (environmental) cooperation is affected by the following forms of domestic pressure: electoral delegation (both strategic and non-strategic), lobbying and media capture by special interest groups, and the impact of domestic influences on the depth of (and participation to) international climate policies. The overarching theme of the review is the focus on a hierarchical notion of policy making: we concentrate on studies that either explicitly or implicitly shed light on how domestic political competition in a country affects the country's international policy. Due to constraints on data availability, most of the reviewed works are theoretical or experimental, although we have included a selection of empirical papers on lobbying and media capture.

In the following Sections 2 and 3, we discuss the two most important channels of domestic political influence, which are (strategic) delegation, and lobbying and media capture, respectively. In Section 4 we first introduce the two most important international climate policies, which are international environmental agreement and international permit markets (Section 4.1), before we discuss the nascent literature analyzing the influence of domestic politics on international climate policy (Section 4.2). Finally, Section 5 summarizes the main findings and advances proposals for future research endeavors.

\section{STRATEGIC DELEGATION AND THE PROVISION OF PUBLIC GOODS}

\subsection{Theoretical Models of Voting and Delegation}

First, we consider instances where the relationship between domestic and international policy is governed by the "hierarchical" structure of policymaking. The underlying idea is that political decisions in modern societies are not made by a single - let alone benevolent - decision maker. For example, representative democracies typically feature a chain of delegation from voters to those who govern (Strøm 2000): (i) from voters to elected representatives, (ii) from legislators to the executive branch (head of government), (iii) from the head of government to the heads of different executive departments, and (iv) from these heads to civil servants. ${ }^{3}$

\footnotetext{
${ }^{3}$ While for autocratic regimes the first link of this chain is obviously missing, we still observe delegation patterns as in (ii), (iii) and (iv).
} 
In all these situations, one party (an agent) acts on behalf of another (the principal). In case principals delegate to agents who exhibit different preferences than they do themselves (e.g., more or less concern with respect to climate change) they delegate strategically.

The literature on strategic delegation emerged in the Industrial Organization literature analyzing the delegation of managerial decisions from shareholders to chief executive officers (for an excellent survey see Kopel and Pezzino 2018). Subsequently, the concept of strategic delegation found its way into the literature on negotiation and cooperation (Burtraw 1992, 1993; Crawford and Varian 1979; Jones 1989; Segendorff 1998; Sobel 1981), where it has been utilized in various contexts with inter-agent spillovers, such as environmental policy or the provision of public goods more generally. ${ }^{4}$

Siqueira (2003), Buchholz et al. (2005), Roelfsema (2007) and Hattori (2010) analyze strategic voting in the context of cross-country externalities in a two country setting. Siqueira (2003) and Buchholz et al. (2005) both find that voters' selection of agents is biased toward politicians who are less concerned about the externality than the median voter. By electing a more "conservative" politician, the home country commits itself to a lower tax on the externality, shifting the burden of abatement to the foreign country. By contrast, Roelfsema (2007) accounts for emissions leakage through shifts in production and finds that median voters may delegate to politicians who place greater weight on environmental damage than they do themselves, whenever their preferences for the environment relative to their valuation of firms' profits are sufficiently strong. However, this result breaks down in the case of perfect pollution spillovers, such as the emission and diffusion of greenhouse gases. Hattori (2010) allows for different degrees of product differentiation and alternative modes of competition, i.e., competition on quantities but also on prices. His general finding is that, when the policy choices are strategic substitutes (complements), a less (more) green policy maker is elected in the non-cooperative equilibrium.

Strategic delegation in the provision of public goods with cross-border externalities more generally (but still in a two country set-up) has been examined by Kempf and Rossignol (2013) and Loeper (2017). The authors of the former paper show that any international agreement that is negotiated by national delegates involves higher public good provisions than in the case of non-cooperative policies, taking feasibility, efficiency and equity constraints into account. In their model, the choice of delegates is highly dependent on the distributive characteristics of the proposed agreement. Loeper (2017) proves that whether cooperation between national delegates is beneficial only depends on the type of public good considered and, more specifically, on the curvature of the demand for the public good but not on voters' preferences, the magnitude of the cross-border externalities, nor the size, bargaining power or efficiency of

\footnotetext{
${ }^{4}$ Strategic delegation is often called "strategic voting" when the principal is the electorate or, more precisely, the median voter and the elected government is the agent (e.g., Persson and Tabellini 1992).
} 
each country in providing the public good.

\subsection{Lab Experiments on Delegation}

There is an extensive experimental economic literature on linear public goods games. ${ }^{5}$ The early literature till the mid 1990s found two main results: (i) In one-shot public goods games, participants' contributed on average approximately half their endowment to the public good, which is half-way between the socially optimal contribution and the non-cooperative Nash equilibrium contribution predicted by non-cooperative game theory. Yet, individual contribution covered the full range from $0 \%$ to $100 \%$. (ii) In environments, where the one-shot public goods game was played repeatedly, average contributions to the public good started at approximately $50 \%$ (as in the one-shot game) and declined with increasing number of repetitions. ${ }^{6}$

An important question is whether and to what extent delegation can foster public goods provision within and across groups. Laboratory experiments allow the researcher to disentangle the effect of adding different layers of the above-mentioned hierarchical structure in a controlled manner. Yet, the experimental literature on delegation and public goods provision is surprisingly sparse. ${ }^{7}$ Several studies report that the free-riding incentives in public goods provision within groups can at least be alleviated by different institutions of delegation. For example, Güth et al. (2007) find that "leading by example", i.e., one player appointed as leader (either by election or random assignment) first contributes, then all other players after observing the leader's contribution decide about their own contribution, significantly increases public goods provisions. Yet, this leading-by-example effect is drastically reduced if player's endowments are heterogeneous across players or private information (Levati et al. 2007). Another institutional design for leadership is that leaders make non-binding contribution suggestions to players prior to the players' contribution choices. Levy et al. (2011) show that leaders' contribution suggestions indeed have an significant effect on players' contributions. They find that leader suggestions act as upper-bound to the player's contribution schedules. While on average leadership has a positive effect on public goods provision, it is detrimental in case that leaders suggest low contributions. Kroll et al. (2007) investigate whether and to what extent a non-binding vote on the provision of a public good prior to the contribution stage can increase

\footnotetext{
${ }^{5}$ In linear public goods games, $n$ players simultaneously split a given endowment between a private and a public account. Players' pay-offs are their private accounts plus the total sum over all players to the public account multiplied by some fraction $\alpha$ (marginal per capita return) with $0<\alpha<1<n \alpha$. Under these circumstances, non-cooperative game theory predicts that, if players only care about their own pay-offs, all players assign the full endowment to the private account, while the Pareto dominating social optimum would be that all players allocate their full endowment to the public account.

${ }^{6}$ See Ledyard (1995) and Chaudhuri (2011) for excellent surveys on linear public goods experiments.

${ }^{7}$ There exists also a small and recent literature testing strategic delegation in other experimental contexts, such as the ultimatum game (e.g., Choy et al. 2016; Fershtman and Gneezy 2001), the dictator game (e.g., Bartling and Fischbacher 2012; Hamman et al. 2010) and bargaining (e.g., Schotter et al. 2000).
} 
public goods provision. They find that voting alone does not yield substantially higher public goods contributions. If, however, voting is combined with a costly punishing mechanism, in which players who deviate from the majority proposal can be punished, significantly decreases free-riding incentives.

A related strand of literature studies institutions in which leaders have more formal power over the other players' contributions. Oxoby (2013) investigates a one-shot public goods game in which players can either directly mandate the contributions of others or at least limit their feasible choice set. He finds that dictated contribution levels are significantly higher and even approximate socially efficient levels. Interestingly, if players can dictate different contribution levels for themselves and all other players, almost $70 \%$ of players manage to resist the temptation to free-ride on the mandated contributions of the others. Bolle and Vogel (2011), however, report that this altruistic behavior deteriorates over time in repeated public goods provision games. In addition, players voluntarily submit to an institution in which one leader dictates the contributions of all group members (Fleiß and Palan 2013; Hamman et al. 2011). Another possible delegation institution is to delegate punishment. Andreoni and Gee (2012) find that a "hired gun" that exhibits a non-exclusive power to punish often results in full compliance in which no punishment is exerted. In addition, punishment - in case it is exerted - is relatively small and, therefore, cost-effective.

Kocher et al. (2018) is the only paper we are aware off that analyzes delegation in a linear public goods game across groups. In their setup, nine players are divided into three groups consisting of three players each. Each group elects a group leader who mandates contributions to the public good for all members of their group. Public good provision, however, depends on the contributions on all nine players across all three groups. This setup is most closely related to the theoretical literature on strategic delegation and public goods provision (see Section 2.1). However, due to the linear public goods technology, there are no incentives to strategically delegate to exploit the strategic substitutability of public goods provision choices. In line with similar experiments of delegation within groups the authors find that (i) delegation increased public good provision compared to the case of non-delegation, ${ }^{8}$ (ii) delegates mainly refrain from exploiting their group members, and (iii) contributions within groups decline over time, although slower than in the case of non-delegation.

\footnotetext{
${ }^{8}$ However, this effect is exclusively due to alleviating the common action problem within each group, free-riding incentives across groups remain.
} 


\section{SPECIAL INTEREST GROUPS AND DOMESTIC CLIMATE POLICY}

\subsection{Lobbying and Environmental Legislation}

Established empirical evidence and political economy models demonstrate that public interest is not the sole objective of politicians. Public officials are motivated, at least to some degree, by their own private interests as well, which in turn makes them vulnerable to be swayed by the influence of national political competition (e.g., Besley 2006; Bombardini and Trebbi 2020; Grossman and Helpman 2001; Persson and Tabellini 2000). The importance of lobby groups in passing or watering down environmental policies has been underscored both in economics (e.g., Oates and Portney 2003) and in environmental politics (e.g., Markussen and Svendsen 2005; Michaelowa 1998 in Europe and Bryner 2008; Kamieniecki 2006 in the US).

This opportunity for interference has been taken up by lobbyists in an attempt to influence political decisions on behalf of individuals and organizations. Such efforts may result in the proposal of new legislation, or the amendment of existing laws and regulations. At the cost of oversimplifying, environmental policy-making is frequently portrayed as a competition between business and environmental lobby groups. Business lobby groups usually aim to limit the scope of costly environmental measures, while environmental lobby groups do the opposite. Below we take a closer look at papers dealing with domestic lobbying, with special attention on its effect on climate change policy.

Formally, the influence of lobby groups on incumbent governments is often modeled by the so called "common agency" approach, originally developed by Bernheim and Whinston (1986) and extended by Grossman and Helpman in various seminal contributions (Grossman and Helpman 1994, 1995a,b). In this setting, lobby groups, in a first step, simultaneously and non-cooperatively offer "contribution schedules", i.e., functions specifying the contribution contingent on implemented policy. In a second step, politicians decide on the policy, taking into account the contribution schedules of lobby groups. This is also the approach Lai (2007, 2008) employs in two papers to analyze the impact of lobbying on the performance of a domestic emission permit market. Lai (2007) finds in a setting where firm and environmental lobby groups influence the decision of the emission cap that the fraction of grandfathered permits to the industry can act as a policy lever to mitigate the welfare decreasing effect of lobbying. In Lai (2008) also the amount of grandfathered permits is endogenized and subject to the political influence by firm and environmental lobbies. In this case, environmental groups lobby for grandfathered permits, as this increases the endowment effect of permits for the firms and, therefore, induce firm lobbies in the second step to lobby for a tighter emission cap to maximize the value of the grandfathered permits. This contradicts the conventional wisdom that 
firm lobbies are usually in favor of a less stringent emission cap.

Bombardini and Trebbi (2020) is a recent review of the political economy literature on lobbying that assesses the degree to which the influence exerted by special interest groups on the government is distortive and ultimately costly from the point of view of the electorate. Specifically, they focus on studies that aim to define and evaluate empirically what the effect on the ensuing policy is, relative to the counterfactual policy that would have been implemented absent the political influence. They conclude that only a handful of studies allow for a clear estimate of the welfare effects of lobbying, depicting a more nuanced view than that held by the majority of laypeople in the US, who seem to believe that lobbying is just a tool to distort public policy. ${ }^{9}$

What about climate change policy? Is there evidence that lobbying activity is distorting welfare away from the social optimum? To get a sense of the magnitude of lobbying expenditure on climate change in the US, Brulle (2018) compiles data on lobbying expenditures for the period 2000-2016 and finds that more than 2 billion US dollars were spent on climate lobbying, accounting for approximately $3.9 \%$ of total lobbying expenditure on average (and peaking in 2009 at about 9 per cent). While large, these figures do not provide a direct answer to the above question. In principle, it may be the case that lobbying is ineffective, for instance because spending aimed at opposing climate mitigation is matched by an equal amount of expenditures in support of tighter regulation, resulting in a wasted effort by special interest groups that end up "burning money" while failing to distort policy.

To causally tackle the above questions, Meng and Rode (2019) investigate the reasons why a carbon tax is yet to pass in the US Congress. To this end, they analyze the Waxman-Markey cap and trade bill, which failed to be enacted in 2009. Based on data on firm lobbying expenses related to this bill, and on a prediction market event study, they infer which firms were expected to gain or lose from the policy, and by how much. They find a positive statistically significant relationship between the firm lobbying expenditure and how much the policy is expected to alter its stock prices: such relationship differs between firms expected to gain from the bill and those expected to lose. Lastly, these relationships are mapped to probabilities of enactment of the policy. The main finding is that firms that are expected to lose from the bill are more effective at lobbying to lower the likelihood of enactment than firms that are expected to gain from the bill. Meng and Rode (2019) conclude that, given the greater effectiveness of oppositional lobbying, the overall lobbying activity decreased the enactment probability of the Waxman-Markey bill by $13 \%$.

\footnotetext{
${ }^{9}$ The authors reference a recent survey from the Pew Research Center that find that $53 \%$ of respondents considered the role of lobbyists and special interest groups in Washington to be a "very big problem".
} 


\subsection{Media Capture and Climate Policy}

The above section demonstrated how environmental public policy is vulnerable to the distortive pressure of well-funded lobbyists, at a potentially high cost for the electorate. But politicians are not the only ones facing a tradeoff between satisfying the interests of one group relative to those of special interest groups. In a similar vein, advertisers may attempt to "capture" media outlets, so as to bias coverage towards their interests. More precisely, MungiuPippidi (2013:41) gives the following definition: "By media capture I mean a situation in which the media have not succeeded in becoming autonomous in manifesting a will of their own, nor able to exercise their main function, notably of informing people. Instead, they have persisted in an intermediate state, with vested interests, and not just the government, using them for other purposes."

A recent literature has found evidence of different channels of media capture. ${ }^{10}$ Earlier work in economics focused on ownership Corneo 2006, bribery (Besley and Prat 2006) and advertising (Petrova 1972). Specifically, Corneo (2006) highlights the role of media in informing citizens' decisions about alternative policy options. He finds that, especially in societies characterized by large inequalities in wealth, special interest groups are more likely to pressure and collude with media owners to bias coverage in support of the policy option that is most advantageous to the interest group (and, possibly, against the public interest). Besley and Prat (2006) study theoretically the effect of media capture on political outcomes, by modeling media outlets' profits as partly driven by commercial relations or collusion with government. To advance their agenda, media owners either bribe the government or attempt to influence legislative interventions in industries affecting them. Petrova (1972) focuses instead on the role of media in manipulating the public opinion, and shows that the problem is more severe in countries with larger income inequality, since the well-off have more opportunities to pay to bias information.

Many studies have followed suit and attempted to empirically estimate the effect of media capture on beliefs about climate change. The underlying question is whether carbon-intensive firms peddle skepticism through advertising and media capture. Such question is highly consequential, since beliefs are relevant, among other things, for voting decisions. ${ }^{11}$

Much of the climate change economics literature agrees by answering with a qualified yes to the above question. Here we briefly review some relevant papers. ${ }^{12}$ Based on a study of newspaper coverage in the US, Boykoff and Boykoff (2004) find that over half of a random

\footnotetext{
${ }^{10}$ See Schiffrin (2017) for a review.

${ }^{11}$ Della Vigna and Kaplan (2007) illustrate the effect of the entry of Fox News in cable markets: Republicans gained vote share in towns that broadcast Fox News. Relatedly, Gentzkow (2006) shows that television may also influence the voter turnout.

${ }^{12}$ See Washington and Cook (2011) for a comprehensive review of the literature that demonstrates that carbonemitting industries are among the largest funders of climate-skeptical research.
} 
sample of articles deny climatic change or refer to it in terms of natural fluctuations. Boykoff (2008) finds further evidence of biased reporting when analyzing US television news, which are more heavily funded by advertising, and typically owned by larger and more concentrated companies, compared to the national print media.

Shapiro (2016) models the mechanism behind information diffusion, with a view to understanding when public policy is likely to reflect the best scientific information, and to study the effect of the institutional design of the news media on the quality of reporting. He finds that "the gap between the equilibrium policy and the ideal policy is wider the greater is the likelihood that the facts are unambiguous, because special interests have an especially strong incentive to manufacture counter-claims in the face of unambiguous evidence." The paper then tests and finds empirical support for this prediction in the context of climate change. Specifically, public acceptance of climate change is greater in countries where media abstain from reporting skeptics' claims.

Lastly, Beattie (2019) finds empirical evidence of climate change-related media capture in the US by the automotive industry (which generates almost two-thirds of newspapers revenues through advertisements), especially for high emission vehicles such as trucks. He estimates the effect of advertising on coverage and finds a negative relationship between potential advertising from car manufacturers and the environmental tone (and amount) of climate change coverage. As a result, coverage of climate change is more skeptical than it would have been in the absence of advertising.

\section{INTERNATIONAL CLIMATE COOPERATION UNDER DOMESTIC POLITICAL ECONOMY CONSTRAINTS}

This section builds on the analyses reviewed thus far. It concentrates on how the domestic pressures aimed at steering the policy makers and public opinion in the direction preferred by special interest groups play out at the international stage.

With respect to international climate policy we tend to observe two different approaches. On the one hand, the UNFCCC (United Framework Convention on Climate Change) governs and conducts regular global negotiations, which resulted in large multilateral agreements such as the Kyoto Protocol or the Paris Agreement. On the other hand, there are bilateral or regional initiatives, a prime example of which are the linking of permit markets, such as the Western Climate Initiative (WCI) and the Regional Greenhouse Gas Initiative (RGGI) in North America.

Both the existing theoretical and experimental economic literature analyze both of these approaches to international climate cooperation predominantly under the assumption that countries behave as individual actors. In addition, the theoretical literature mostly applies a 
partial equilibrium framework in which countries' domestic welfares only comprise of some benefits due to domestic GHG emissions and environmental damages depending on the global level of GHG emissions. Although the experimental literature usually finds more cooperation than predicted by theory (see Section 2.2), the overall conclusion is rather pessimistic regarding the prospects of international environmental cooperation.

In the following, we briefly review the established literature dealing with international environmental agreements and international emission permit markets, before revisiting the mechanisms that we reviewed in Sections 2 and 3, but with a focus on models that specifically address the repercussions of electoral delegation and domestic lobbying on international climate policy.

\subsection{International Environmental Agreements and Emission Permit Markets}

Since the 1990's one strand of economic literature has explored the possibilities of international (environmental) cooperation by analyzing the formation and stability of so-called selfenforcing ${ }^{13}$ international agreements in a multi-stage game theoretical model: In the first stage countries decide whether to join a climate coalition. In the second stage coalition members are assumed to cooperate by choosing emission levels that maximize their joint pay-off, while noncoalition members set emission levels maximizing their domestic welfare only. This game design is also known as coalition formation game. The pioneering contributions of Barrett (1993), Carraro and Siniscalco (1993) and Hoel and Schneider (1997), among others, have been extended along various dimensions: participation constraints (e.g., Carraro et al. 2009; Weikhard et al. 2015), uncertainty and learning (e.g., Finus and Pintassilgo 2013; Kolstad 2007; Kolstad and Ulph 2008), international trade (e.g., Eichner and Pethig 2013, 2015) and technology investments (e.g., Barrett 2006; Battaglini and Harstad 2016; Goeschl and Perino 2017; Harstad 2016; Helm and Schmidt 2015) and the possibility of cooperating countries to agree on modest emission abatement targets (e.g., Finus and Maus 2008; Harstad 2020), to name just a few. ${ }^{14}$ In general, this literature derives rather pessimistic predictions about international environmental cooperation: Stable coalitions are either ambitious (with respect to emission reductions) but small or large but modest (again, with respect to emission reductions). In either case, selfenforcing environmental agreements achieve only modest reductions of global GHG emissions against "business-as-usual" (BAU) emissions.

As a consequence, another strand of economic literature has explored the potential of market based institutional designs to facilitate international environmental cooperation. Most no-

\footnotetext{
${ }^{13}$ Self-enforcing means that sovereign countries are reluctant to join or comply with an agreement, as long as this is not in their own self-interest.

${ }^{14}$ For comprehensive surveys of this literature see, e.g., Barrett (2003), Finus (2008), Wagner (2001) and de Zeeuw (2015).
} 
table is the formation of international emission permit markets in which permits can be nondiscriminatorily traded across all participating countries (e.g., Flachsland et al. 2009; Green et al. 2014; Jaffe et al. 2009). On the one hand, international permit markets promise efficiency gains, as marginal abatement costs are equalized across firms and countries, which is a necessary condition for efficiency (Montgomery 1972). On the other hand, it is not straightforward how the permit cap in the combined market is determined. While some authors assume that domestic permit allocations remain unchanged by switching from separate markets to a combined market and study other frictions that may outweigh the efficiency gains and thus prevent linking (e.g., Babiker et al. 2004; Doda and Taschini 2017; Doda et al. 2019), another strand of literature assumes that permit allocations are chosen strategically after countries decided whether to join their permit markets (Helm 2003; Helm and Pichler 2015; Holtsmark and Midttømme 2019; Holtsmark and Sommervoll 2012). In these settings, countries first decide whether to join an international permit market and, in a second step, non-cooperatively choose domestic endowments of emission permits. As a consequence, the total amount of permits in such a trading scheme is not necessarily efficient. In fact, some countries might be tempted to issue more permits than they would do in the absence of international trade in permits, because they might gain from selling permits to other countries.

Yet, even in case of strategically chosen domestic emission permit endowments, international permit markets exhibit substantial potential for GHG reductions under certain circumstances. In particular, linking the permit markets of countries with high carbon efficiency (i.e., high marginal benefits of GHG emissions) and high willingness to pay for emission reductions (i.e., high marginal damages) and countries with low carbon efficiency and low willingness to pay leads to a Pareto improvement, in which efficiency gains due to equalizing marginal abatement costs are realized and total emissions decline. Carbone et al. (2009) demonstrate in a calibrated general equilibrium model that the highest GHG emission reductions would be achieved by establishing an international emission permit market among the EU, the Former Soviet Union and China. Yet, also this coalition achieves GHG emission reduction that only bridges half of the gap between BAU emissions and the globally optimal GHG emission levels.

\subsection{Hierarchical Interplay between Domestic Political Pressure and International Climate Policy}

All of the aforementioned literature shares the assumption that countries are considered as unitary actors, such as benevolent governments, acting in the best interest of the country as a whole. As discussed in Sections 2 and 3, this view on domestic policy is too simplistic. By neglecting any internal political structure of countries any possible interactions between domestic and international (environmental) policy are lost. 
In a recent paper, Battaglini and Harstad (2020) show that domestic political competition may have an important impact on the design and the effectiveness of international agreements. In a model, in which a home country exerts an externality on a foreign country, they show that the political competition for reelection of an incumbent government with a rival party may lead to "weak" treaties, i.e., agreements with control and sanctions mechanisms which cannot ensure that the treaty is obliged with independently of who wins the next election. While these treaties are always inefficient from a social welfare perspective, it is in the best interest of the incumbent government to negotiate a weak treaty if the pay-off of reelection is sufficiently high. The reason is that the incumbent government can increase its reelection probability by a weak treaties, as this allows the incumbent government to further differentiate itself from the competing party.

In the political science literature, Putnam (1988) described the relationship between domestic and international policy as a two-level game: A country's negotiator (e.g., the head of government) is well aware that any treaty agreed upon on the international level will have to be ratified by the respective governmental body in her own country (and also the other countries) before entering into force. Anticipating potential obstacles to ratification will, in general, impact on the negotiator's bargaining behavior on the international level. In a recent paper, Köke and Lange (2017) adopt this view on the relationship between domestic and international climate policy in a political economy set-up, in which the negotiator and the legislator (i.e., the agent that is decisive for domestic ratification) differ in their preferred emission reduction target. They find that larger coalitions with less ambitious emission targets prevail. ${ }^{15}$ While the negotiator and the legislator in Köke and Lange (2017) are supposed to exhibit different preferences with respect to emission abatement, this difference is exogenously given. Thus, it is not explored how they may depend on each other.

A powerful link between domestic and international (climate) policy is the influence of special interest groups on incumbent governments, as discussed in Section 3. Employing a common agency approach to lobbying, Habla and Winkler (2013) analyze the formation of an international emission permit market when the governments of countries are influenced by special interest groups. Governments are supposed to be subject to lobby contributions in both stages: first, when they decide to link domestic permit markets to an international market and, second, when they decide on the amount of permits issued to the domestic industry. They find the counterintuitive result that lobbying may "backfire", i.e., an increase in power of a particular lobby group may result in a policy change that is considered worse by the lobby group. The reason is that an increase in a lobby group's power has direct and indirect effects. While

\footnotetext{
${ }^{15}$ Interestingly, their model set-up, apart from the political economy framework, essentially reverses the sequence of decisions compared to the standard model in the literature on self-enforcing international agreements. First, countries decide on the emission targets for treaty members and, second, members decide whether to join.
} 
the direct effect leads to a policy change in the desired direction in the own country, there is an indirect effect in the opposite direction on the government of the other country (because of the strategic substitutability of emission permit choices), which may outweigh the direct effect.

Cheng and Chu (2020) also analyze the influence of lobbying on the performance of an international emission permit market, yet they assume that polluting firms are subject to both an international permit market regime and, in addition, a domestic emission tax. ${ }^{16}$ In contrast to Habla and Winkler (2013) they take the formation of an international emission permit market as given and concentrate on the influence of lobbying on domestic and global emissions. In the most realistic regime, in which lobby groups can only influence the domestic emission tax but not the emission permit issuance, they find that an international permit markets is particularly beneficial in reducing global emissions if the firm lobby is strong and the environmental lobby is weak. The reason is that the international permit market determines the level of global emissions. Thus, an international permit market acts as safeguard against the emission increasing influence of firm lobby groups in case of only a domestic emission tax.

Marchiori et al. (2017) analyze the formation of a self-enforcing international environmental agreement when governments' emissions choices are influenced by an industry and an environmental lobby group. While these lobby groups only exert political influence in the second stage, i.e., on the emission levels of countries, this second stage influence percolates into the first stage decision, as it is anticipated by governments when making the decision whether to join the international agreement. They show that a strong industry lobby and/or weak environmental lobby reduces the emissions abatement of participating countries and, thus, may increase participation. Whether the increase in participation outweighs the lower abatement effort of participating countries crucially depends on the number of countries joining the agreement.

Lastly, we take another look at delegation, as discussed in Section 2. In the context of hierarchical international climate policy, delegation can take on various forms. For example, governments may chose and send delegates to international negotiations like in Köke and Lange (2017). Another form of delegation is found in representative democracies, where voters elect a government that takes decisions on their behalf. Anticipating the interaction of the elected government with other (elected) governments in some form of international (climate) cooperation may lead the median voter to strategically elect a government that exhibits different preferences than she has herself. This kind of set-up is often called strategic voting.

In a model consistent with several interpretations of strategic delegation, Habla and Winkler (2018) analyze the formation of international emission permit markets. They find that

\footnotetext{
${ }^{16}$ The UK established a carbon tax that essentially acted as a price floor for $\mathrm{CO}_{2}$ emissions even for installations regulated under the EU-ETS. Whenever the permit price in the EU-ETS is below the domestic carbon tax, firms are subject to both, the international permit market and the domestic carbon tax.
} 
principals have an incentive to delegate strategically and choose agents that exhibit less green preferences than they do themselves. This even holds if emission choices are dominant strategies in autarky, because of the strategic substitutability of emission permit choices that arises from the trade in permits. Permit sellers, in particular, have an incentive to delegate to agents that have much less concern for the environment. This incentive to strategically delegate renders the linking of domestic permit markets to an international market less profitable, in particular for permit buyers. They conclude that this may explain why we hardly observe linking of permit markets in reality, despite their seemingly favorable characteristics.

In a model framework similar to Finus and Maus (2008), i.e., cooperating countries may agree on more modest emission abatement targets instead of full internalization of emission externalities among all participating countries, Spycher and Winkler (2018) analyze the formation of self-enforcing environmental agreements when governments can strategically delegate emission choices. They find that principals in all countries have an incentive to delegate to agents with lower environmental concerns than they exhibit themselves. This strategic delegation incentive is increasing with the number of countries that joined the agreement for principals in non-participating countries, and decreasing for principals of countries joining the agreement. In addition, principals in countries that joined the IEA delegate such that they crowd out all efforts to increase coalition sizes by less ambitious agreements. In summary, strategic delegation weakly decreases the number of participating countries and strictly increases global GHG emissions.

An additional layer of delegation can be found in federal countries, where the federal government may choose to delegate particular decisions to the state governments. Foucart and Wan (2018) analyze the provision of global public goods, such as climate change mitigation, in a strategic federation framework. In the first step, countries decide on the political structure by either leaving public good provision in the hands of the individual states (de-centralization) or to delegate public good provision to the federal government (centralization). In the second step, the responsible entities non-cooperatively decide on their public good provision. On the one hand, centralization offers potential gains by internalizing the exernalities within a federation, on the other hand decentralization allows to more aggressively free-ride on the public good provision of other providers, either within or across countries. In fact, depending of the preference of the public good and their heterogeneity across states, decentralization can be in the best interest of all the members of a federation, as it acts as a commitment to free-riding. Yet, it decreases global public good provision.

Two recent experimental papers complement the aforementioned theoretical literature by studying the effect of delegation in the provision of threshold public goods, a class of games which is of particular importance in the context of (abrupt) climate change. ${ }^{17}$ Milinski et al.

\footnotetext{
${ }^{17}$ In threshold public goods games a public bad can only be avoided if contributions to a public fund exceed
} 
(2016) investigate delegation in a threshold public goods game. Six groups of three players each contribute to a public account over ten rounds. Within each group, one player is either randomly selected or elected by the other players to make contributions on behalf of the group. If the public account is below a certain threshold after ten rounds, there is a $90 \%$ probability that private accounts are lost. They compare outcomes of this treatment with delegation to similar treatments without delegation of eighteen and six players. While group investments and also the probability that the threshold is reached do not significantly vary across treatments, they find some evidence (only statistically significant in some treatments) that players in the delegation treatment elect representatives who contribute less than average in order to extort higher contributions from other groups, in line with the literature on strategic delegation and public goods provision.

The second experiment explores the relationship between delegation and public pressure in a threshold public goods game. İriş et al. (2019) randomly assign twelve subjects into four teams, and ask each team to elect a delegate through majority voting. The elected delegates play several variants of a one-shot threshold public goods game, in which losses can ensue if the sum of their contributions falls short of a threshold and earnings are split evenly among the team members. They find that when delegation is coupled with public pressure, it has a significantly negative effect on contributions, even though the constituency can only exert mild pressure on the delegate, in the form of suggested contributions. The reason is that delegates give more weight to the least cooperative suggestion: they focus on the lower of the two public good contributions recommended by their teammates.

\section{CONCLUSIONS}

Despite the COVID-19 pandemic, the mitigation of anthropogenic climate change remains one of the most important challenges humanity currently faces. Although there is a widespread consensus on the long-term policy goal that the increase of the average surface temperature should be contained below $2^{\circ} \mathrm{C}$ compared to the pre-industrial level, the international community consistently fails to coordinate on appropriate measures. As a consequence, a better understanding of the obstacles and opportunities that the interactions between domestic and

a particular threshold. The relationship to anthropogenic climate change is as follows: only if greenhouse gas emission abatements are provided on a globally sufficient level, the temperature increase against preindustrial levels can be contained below a certain threshold, say $2{ }^{\circ} \mathrm{C}$, in order to prevent drastic and maybe irreversible consequences of climate change. In contrast to linear public goods games, which are always prisoners' dilemma games, threshold public goods games are coordination games with two sets of stable Nash equilibria if the public good provision technology is sufficiently efficient (or the public bad sufficiently severe): (i) an inefficient equilibrium in which no player contributes and (ii) a set of efficient equilibria in which the threshold is just met and, thus, the public good is provided (or the public bad prevented, respectively). See Barrett and Dannenberg (2012); Bosetti, Heugues, and Tavoni (2017); Dannenberg et al. (2015); Milinski et al. (2008); Tavoni et al. (2011) for threshold public goods experiments on climate change mitigation. 
international policy pose for the design of successful international climate cooperation is of utmost importance.

The existing literature on international (environmental) cooperation, as discussed in Section 4.1 shows that it is exceptionally difficult to achieve the global social optimum in climate change mitigation (or public goods provision, in general), even when considering countries as unitary actors. The main reasons are (i) the public good characteristic of GHG gas emission abatement, (ii) the absence of a strong supranational institution to enforce international cooperation and punish non-participation and non-compliance, and (iii) the heterogeneity of countries. In addition, the general result from a recent theoretical literature on the relationship between domestic and international climate policy, which we discussed in Section 4.2, finds that considering the interactions between domestic and international climate policy renders international cooperation even more difficult (e.g., Buchholz et al. 2005; Habla and Winkler 2013, 2018; Marchiori et al. 2017; Siqueira 2003; Spycher and Winkler 2018). The reason is that emission choices are strategic substitutes in the standard partial equilibrium model employed in this literature when marginal damages of global emissions are increasing. This general result is confirmed by experiments that study strategic delegation in threshold public goods games (e.g., İriş et al. 2019; Milinski et al. 2016.

Yet, it is not clear whether emission choices are necessarily strategic substitutes. It is well known that richer model designs create incentives in the direction of strategic complementarity. For example, international trade in goods may render emission choices strategic complements rather than substitutes (e.g., Copeland and Taylor 2005; Eichner and Pethig 2013, 2015; Hattori 2010). The reason is that, in addition to the direct strategic effect, which is always negative (i.e., emission choices are strategic substitutes), there is an impact of the change in the world goods prices induced by the changes in other countries' emission levels. This termsof-trade effect can be either positive or negative. If the price effect is positive and sufficiently strong it may even outweigh the direct strategic effect. In this case, the respective country views the emission choices of all other countries as strategic complements. This would reverse the impact of strategic delegation on international public good provision. Instead of delegating to agents with less green preferences, principles would choose agents with higher concern for the environment than they exhibit themselves, which would partly mitigate the underprovision of global GHG abatement.

While we are not aware of any papers in this direction and we consider this an important and fruitful avenue for future research, we do not believe that the effects of strategic complementarity are strong enough to bring global GHG emissions down to efficient levels. ${ }^{18}$ Yet, there is another perspective on delegation. In the hierarchical policy setting discussed in this

\footnotetext{
${ }^{18}$ Because in this case the provision of global public goods is not a prisoner's dilemma but a coordination game and efficient provision would be (relatively) easy to achieve. This is not what we currently observe with respect to climate change mitigation.
} 
review, principals have an incentive to strategically delegate, as this acts as a credible commitment device to bind oneself to a future policy: if emission choices are strategic substitutes, emission choices are delegated to agents with less green preferences because it is correctly anticipated by the other countries that this agent will decide on a less stringent climate policy than the principal would have done. The combined effect of the governance structure of representative democracies and the strategic substitutability of emission choices thus lead to an amplification of the issue of underprovision of a global public good such as GHG mitigation.

Yet, delegation could also be strategically used in the design of international climate policy. For example, countries setting up an international permit market will need an institution that conducts the international trade of permits. Also the decision regarding the fraction of permits to be grandfathered to firms in all participating countries could be delegated to this institution to safeguard the international permit market against detrimental influences of domestic lobby groups in the individual countries' choices of emission permit issuance. ${ }^{19}$ While delegation in such an international setting has to be beneficial to all countries, otherwise they would not consent to it, it is conceivable that at least under certain circumstances this is case. To the best of our knowledge, the economic literature on international climate policies has not yet started to explore the role of delegation in the design of international treaties. In our opinion, this would be another promising direction for future research.

\section{DISCLOSURE STATEMENT}

The authors are not aware of any affiliations, memberships, funding, or financial holdings that might be perceived as affecting the objectivity of this review.

\section{ACKNOWLEDGMENTS}

We gratefully acknowledge financial support of the Swiss National Science Foundation, project no. 189163.

\section{References}

Andreoni J, Gee L. 2012. Guns for hire: Delegated enforcement and peer punishment in public goods provision. Journal of Public Economics 96:1036-1046

Babiker M, Reilly J, Viguier L. 2004. Is international emissions trading always beneficial? Energy fournal 25:33-56

\footnotetext{
${ }^{19}$ See the discussion of Lai (2007) in Section 3.1.
} 
Barrett S. 1993. Self-enforcing international environmental agreements. Oxfrod Economic Papers 46:878-894

Barrett S. 2003. Environment and Statecraft: The Strategy of Environmental Treaty-making. New York: Oxford University Press

Barrett S. 2006. Climate treaties and "breakthrough" technologies. American Economic Review $96: 22-25$

Barrett S, Dannenberg A. 2012. Climate negotiations under scientific uncertainty. Proceedings of the National Academy of Sciences 109:17372-17376

Bartling B, Fischbacher U. 2012. Shifting the blame: On delegation and responsibility. Review of Economic Studies 79:67-87

Battaglini M, Harstad B. 2016. Participation and duration of environmental agreements. Fournal of Political Economy 124:160-204

Battaglini M, Harstad B. 2020. The political economy of weak treaties. Fournal of Political Economy 128:544-590

Beattie G. 2019. Advertising and media capture: The case of climate change. Journal of Public Economics 188:104219

Bernheim B, Whinston M. 1986. Menu auctions, resource allocation, and economic influence. Quarterly fournal of Economics 101:1-31

Besley T. 2006. Principled Agents? The Political Economy of Good Government. Oxford: Oxford University Press

Besley T, Prat A. 2006. Handcuffs for the grabbing hand? Media capture and government accountability. American Economic Review 3:720-736

Bolle F, Vogel C. 2011. Power comes with responsibility-or does it? Public Choice 148:459-470

Bombardini M, Trebbi F. 2020. Empirical models of lobbying. Annual Reviews of Economics 12:391-413

Bosetti V, Heugues M, Tavoni A. 2017. Luring others into climate action: Coalition formation games with threshold and spillover effects. Oxford Economic Papers 69:410-431

Boykoff MT, Boykoff JM. 2004. Balance as bias: Global warming and the US prestige press. Global Environmental Change 14:125-136

Boykoff MT. 2008. Lost in translation? United States television news coverage of anthropogenic climate change, 1995-2004. Climatic Change 86:1-11

Brulle RJ. 2018. The climate lobby: A sectoral analysis of lobbying spending on climate change 
in the USA, 2000 to 2016. Climatic change 149:289-303

Bryner G. 2008. Failure and opportunity: Environmental groups in US climate policy. Environmental Politics 17:319-336

Buchholz W, Haupt A, Peters W. 2005. International environmental agreements and strategic voting. Scandinavian fournal of Economics 107:175-195

Burtraw D. 1992. Strategic delegation in bargaining. Economics Letters 38:181-185

Burtraw D. 1993. Bargaining with noisy delegation. RAND fournal of Economics 24:40-57

Carbone J, Helm C, Rutherford T. 2009. The case for international emission trade in the absence of cooperative climate policy. Fournal of Environmental Economics and Management 58:266280

Carraro C, Marchiori C, Oreffice S. 2009. Endogenous minimum participation in international environmental agreements. Environmental and Resource Economics 42:411-425

Carraro C, Siniscalco D. 1993. Strategies for the international protection of the environment. fournal of Public Economics 52:309-328

Chan G, Stavins R, Ji Z. 2018. International climate change policy. Annual Review of Resource Economics 10:335-360

Chaudhuri A. 2011. Sustaining cooperation in laboratory public goods experiments: A selective survey of the literature. Experimental Economics 14:47-83

Cheng C-c, Chu H. 2020. International emissions trading in a political economy. Review of International Economics 28:429-446

Choy A, Hamman J, King R, Weber R. 2016. Delegated bargaining in a competitive agent market: An experimental study. fournal of the Economic Science Association 2:22-35

Copeland B, Taylor M. 2005. Free trade and global warming: A trade theory view of the Kyoto Protocol. Journal of Environmental Economics and Management 49:205-234

Corneo G. 2006. Media capture in a democracy: The role of wealth concentration. fournal of Public Economics 90:37-58

Crawford V, Varian H. 1979. Distortion of preferences and the Nash theory of bargaining. Economics Letters 3:203-206

Dannenberg, A, Löschel A, Paolacci G, Reif C, Tavoni A. 2015. On the provision of public goods with probabilistic and ambiguous thresholds. Environmental and Resource Economics 61:365383.

Della Vigna S, Kaplan E. 2007. The Fox News effect: Media bias and voting. Quarterly fournal 
of Economics 122:1187-1234

Doda B, Taschini L. 2017. Carbon dating: When is it beneficial to link ETSs? Fournal of the Association of Environmental and Resource Economists 4:701-730

Doda B, Quemin S, Taschini L. 2017. Linking permit markets multilaterally. Journal of Environmental Economics and Management 98:102259

Eichner T, Pethig R. 2013. Self-enforcing environmental agreemnets and international trade. fournal of Public Economics 102:37-50

Eichner T, Pethig R. 2015. Is trade liberalization conducive to the formation of climate coalitions? International Tax and Public Finance 22:932-955

Fershtman C, Gneezy U. 2001. Strategic delegation: An experiment. RAND fournal of Economics $32: 352-368$

Finus M. 2008. Game theoretic research on the design of international environmental agreements: Insights, critical remarks, and future challenges. International Review of Environmental and Resource Economics 2:29-67

Finus M, Maus S. 2008. Modesty may pay. Journal of Public Economic Theory 10:801-826

Finus M, Pintassilgo P. 2013. The role of uncertainty and learning for the success of international climate agreements. Journal of Public Economics 103:29-43

Flachsland C, Marschinski R, Edenhofer O. 2009. To link or not to link: Benefits and disadvantages of linking cap-and-trade systems. Climate Policy 9:358-372

Fleiß J, Palan S. 2013. Of coordinators and dictators: A public goods experiment. Games 4:584607

Foucart R, Wan C. 2018. Strategic decentralization and the provision of global public goods. fournal of Environmental Economics and Management 92:537-558

Gentzkow M. 2006. Television and voter turnout. Quarterly fournal of Economics 121:931-972

Goeschl T, Perino G. 2017. The climate policy hold-up: green technologies, intellectual property rights, and the abatement incentives of international agreements. Scandinavian fournal of Economics 119:709-732

Green JF, Sterner T, Wagner G. 2014. A balance of bottom-up and top-down in linking climate policies. Nature Climate Change 4:1064-1067

Grossman GM, Helpman E. 1994. Protection for sale. American Economic Review 84:833-850

Grossman GM, Helpman E. 1995a. The politics of free-trade agreements. American Economic Review 85:667-690 
Grossman GM, Helpman E. 1995b. Trade wars and trade talks. Fournal of Political Economy 103:675-708

Grossman GM, Helpman E. 2001. Special interest politics. Cambridge, MA and London: MIT Press

Güth W, Levati M, Sutter M, van der Heijden E. 2007. Leading by example with and without exclusion power in voluntary contribution experiments. Fournal of Public Economics 91:10231042

Habla W, Winkler R. 2013. Political influence on non-cooperative international climate policy. fournal of Environmental Economics and Management 66:219-234

Habla W, Winkler R. 2018. Strategic delegation and international permit markets: Why linking may fail. Journal of Environmental Economics and Management 92:244-250

Hamman J, Loewenstein G, Weber R. 2010. Self-interest through delegation: An additional rationale for the principal-agent relationship. American Economic Review 100:1826-1846

Hamman J, Weber R, Woon J. 2011. An experimental investigation of electoral delegation and the provision of public goods. American fournal of Political Science 55:738-752

Harstad B. 2016. The dynamics of climate agreements. Fournal of the European Economic Association 14:719-752

Harstad B. 2020. Pledge-and-review bargaining: From Kyoto to Paris. Unpublished Manuscript, June 2020

Hattori K. 2010. Strategic voting for noncooperative environmental policies in open economies. Environmental and Resource Economics 46:459-474

Helm C. 2003. International emissions trading with endogenous allowance choices. fournal of Public Economics 87:2737-2747

Helm C, Pichler S. 2015. Climate policy with technology transfers and permit trading. Environmental and Resource Economics 60:37-54

Helm C, Schmidt R. 2015. Climate cooperation with technology investments and border carbon adjustment. European Economic Review 75:112-130

Hoel M, Schneider K. 1997. Incentives to participate in an international environmental agreement. Environmental and Resource Economics 9:153-170

Holtsmark K, Midttømme K. 2019. The dynamics of linking permit markets. CESifo Working Paper No. 7548, March 2019

Holtsmark B, Sommervoll D. 2012. International emissions trading: Good or bad? Economics 


\section{Letters 117:362-364}

İriş D, Lee J, Tavoni A. 2019. Delegation and public pressure in a threshold public goods game. Environmental and Resource Economics 74:1331-1353

Jaffe J, Ranson M, Stavins RN. 2009. Linking tradable permit systems: A key element of emerging international climate policy architecture. Ecology Law Quarterly 36:789-808

Jones S. 1989. Have your lawyer call my lawyer: Bilateral delegation in bargaining situations. fournal of Economic Behavior and Organization 11:159-174

Kamieniecki S. 2006. Corporate America and Environmental Policy: How Often Does Business Get its Way? Palo Alto, CA: Stanford University Press

Kempf H, Rossignol S. 2013. National politics and international agreements. Journal of Public Economics 100:93-105

Kocher M, Tan F, Yu J. 2018. Providing global public goods: Electoral delegation and cooperation. Economic Inquiry 56:381-397

Köke S, Lange A. 2017. Negotiating environmental agreements under ratification constraints. fournal of Environmental Economics and Management 83:90-106

Kolstad C. 2007. Systematic uncertainty in self-enforcing international environmental agreements. Journal of Environmental Economics and Management 53:68-79

Kolstad C, Ulph A. 2008. Learning and international environmental agreements. Climatic Change 89:125-141

Kopel M, Pezzino M. 2018. Strategic delegation in oligopoly. In Handbook of Game Theory and Industrial Organization, Volume II: Applications, ed. L Corchón, M. Marini, chapter 10. Cheltenham: Edward Elgar

Kroll S, Cherry T, Shogren J. 2007. Voting, punishment, and public goods. Economic Inquiry 45:557-570

Lai Y-B. 2018. The optimal distribution of pollution rights in the presence of political distortions. Environmental and Resource Economics 36:367-388

Lai Y-B. 2018. Auctions or grandfathering: The political economy of tradable emission permits. Public Choice 136:181-200

Ledyard O. 1995. Public goods: Some experimental results. In Handbook of Experimental Economics, ed. J Kagel, A Roth, chapter 2. Princeton: Princeton University Press

Levati M, Sutter M, van der Heijden E. 2007. Leading by example in a public goods experiment with heterogeneity and incomplete information. Journal of Conflict Resolution 51:793-818 
Levy D, Padgitt K, Peart S, Houser D, Xiao E. 2011. Leadership, cheap talk and really cheap talk. Journal of Economic Behavior and Organization 77:40-52

Loeper A. 2017. Cross-border externalities and cooperation among representative democracies. European Economic Review 91:180-208

Marchiori C, Dietz S, Tavoni A. 2017. Domestic politics and the formation of international environmental agreements. Fournal of Environmental Economics and Management 81:115131

Markussen P, Svendsen G. 2005. Industry lobbying and the political economy of GHG trade in the European Union. Energy Policy 33:245-255

Meng KC, Rode A. 2019. The social cost of lobbying over climate policy. Nature Climate Change 9:472-476

Michaelowa A. 1998. Impact of interest groups on EU climate policy. European Environment 8:152-160

Milinski M, Sommerfeld R, Krambeck H-J, Reed F, Marotzke J. 2008. The collective-risk social dilemma and the prevention of simulated dangerous climate change. Proceedings of the National Academy of Sciences 105:2291-2294

Milinski M, Hilbe C, Semmann D, Sommerfeld R, Marotzke J. 2016. Humans choose representatives who enforce cooperation in social dilemmas through extortion. Nature Communications 7:10915

Montgomery W. 1972. Markets in licenses and efficient pollution control programs. fournal of Economic Theory 5:395-418

Mungiu-Pippidi A. 2013. Freedom without impartiality: The vicious circle of media capture. In Media Transformations in the Post-Communist World, ed. P Gross, K Jakubowicz, pp. 33-48. Plymouth: Lexington Books

Oates W, Portney P. 2003. The political economy of environmental policy. In Handbook of Environmental Economics, ed. KG Maeler, J Vincent, pp. 325-354. Amsterdam: Elsevier

Oxoby R. 2013. Paretian dictators: Constraining choice in a voluntary contribution game. Constitutional Political Economy 24:125-138

Persson T, Tabellini G. 1992. The politics of 1992: Fiscal policy and european integration. Review of Economic Studies 59:689-701

Persson T, Tabellini G. 2000. Political Economics: Explaining Public Policy. Cambridge, MA: MIT Press

Petrova M. 2008. Inequality and media capture. fournal of Public Economics 92:183-212 
Putnam RD. 1988. Diplomacy and domestic policy: The logic of two-level games. International Organization 42:427-460

Roelfsema H. 2007. Strategic delegation of environmental policymaking. Fournal of Environmental Economics and Management 53:270-275

Schiffrin A (Ed). 2017. In the Service of Power: Media Capture and the Threat to Democracy. Washington, DC: Center for International Media Assistance

Schotter A, Zheng W, Snyder B. 2000. Bargaining through agents: An experimental study of delegation and commitment. Games and Economic Behavior 30:248-292

Segendorff B. 1998. Delegation and threat in bargaining. Games and Economic Behavior 23:266283

Shapiro JM. 2016. Special Interests and the media: Theory and an application to climate change. fournal of Public Economics 144:91-108

Siqueira K. 2003. International externalities, strategic interaction, and domestic politics. Fournal of Environmental Economics and Management 45:674-691

Sobel J. 1981. Distortion of utilities and the bargaining problem. Econometrica 49:597-619

Spycher S, Winkler R. 2018. Strategic delegation in the formation of international environmental agreements. SSRN Working Paper no. 3361731

Strøm K. 2000. Delegation and accountability in parliamentary democracies. European fournal of Political Research 37:261-290

Tavoni A, Dannenberg A, Kallis G, Löschel A. 2011. Inequality, communication, and the avoidance of disastrous climate change in a public goods game. Proceedings of the National Academy of Sciences 108:11825-11829.

Wagner UJ. 2001. The design of stable international environmental agreements: Economic theory and political economy. Fournal of Economic Surveys 15:377-411

Washington H, Cook J. 2011. Climate Change Denial. London: Earthscan

Weikhard H-P., Wangler L, Freytag A. 2015. Minimum participation rules with heterogeneous countries. Environmental and Resource Economics 62:711-727

de Zeeuw A. 2015. International environmental agreements. Annual Review of Resource Economics 7:1.1-1.18 


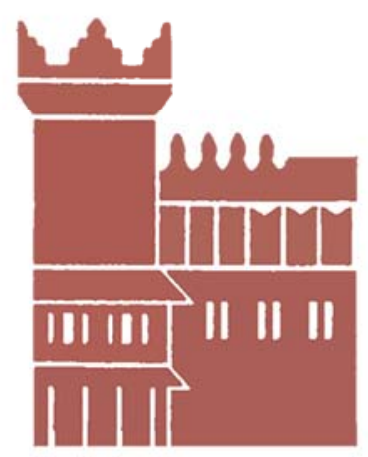

Alma Mater Studiorum - Università di Bologna DEPARTMENT OF ECONOMICS

Strada Maggiore 45

40125 Bologna - Italy

Tel. +39051 2092604

Fax +390512092664

http://www.dse.unibo.it 